\title{
Does Financial Sector Development Enhance the Relationship between FDI and Economic Growth? A Comparative Study of East African Countries
}

\author{
Roger Kelly*
}

\author{
European Investment Bank, 100 Boulevard Konrad Adenauer, L2950 Luxembourg, Luxembourg
}

\begin{abstract}
This study examines the causal relationship between FDI and GDP growth in a number of East African countries, focusing on the impact of financial sector development on this relationship. There are strong theoretical reasons to believe that a developed financial sector will enhance the impact of FDI on growth, but empirical evidence remains scant. This study looks first at the short term causal relationship between FDI and GDP growth, using a robust methodology that avoids issues associated with Granger causality testing. This testing indicates little evidence of a relationship. Johansen cointegration testing yields little evidence of a long run relationship when a VECM containing just FDI and GDP growth is estimated, however once variables proxying financial sector development and an interaction variable between FDI and financial sector development are included, we find that although FDI and GDP growth may not be cointegrated directly, there is a relationship running through their interaction with the financial sector, and that FDI only appears to have a positive impact on GDP growth in cases where the financial sector is more developed. This finding is in line with the findings of previous researchers, and has important policy implications.
\end{abstract}

Keywords: FDI, Financial Sector Development, Cointegration, Causality.

\section{INTRODUCTION}

FDI is widely seen as a key element in the development process, helping developing countries transition from low to middle income status. Perhaps unsurprisingly, there is a huge literature surrounding the relationship between FDI and economic growth. There is also a significant body of literature looking at the relationship between financial sector development and growth. Some of the literature related to these relationships is reviewed below. However, there has been little in the way of empirical investigation into the importance of financial sector development in enhancing the impact of FDI flows on growth. This is somewhat surprising, as there is an important body of theoretical literature on this topic. This paper seeks to test the hypothesis that financial sector development is an important precondition for FDI to enhance growth using a selection of East African countries as case studies.

East Africa has been chosen because the region contains a number of highly dynamic economies that have seen rapid development in recent years, particularly in their financial sectors. Many of these countries have taken great strides to improve their macroeconomic performance, making them more attractive to foreign investors; not least, they have seen a strengthening in their fiscal positions, the liberalisation of exchange controls, and significant

*Address of correspondence to this author at the European Investment Bank, 100 Boulevard Konrad Adenauer, L2950 Luxembourg, Luxembourg;

Tel: +254 790205445 E-mail: kellyr@eib.org reductions in inflation. At the same time, financial liberalisation, upgrades in institutional and regulatory capacity and the expansion of cross-border banking activities have resulted in a deepening of the financial sectors of a number of countries of the region, making them more stable and resilient. Financial innovation has been particularly important in East Africa, with mobile banking allowing banks to provide services to those even in remote areas. That said, the improvements have not been universal; financial inclusion remains limited, and high costs, short lending maturities, low levels of competition and high levels of concentration inhibit the ability of the countries' financial sectors to reach their full potential in supporting the real economy.

\section{THEORETICAL ASPECTS AND LITERATURE REVIEW}

There is a substantial body of literature that investigates the relationship between FDI and growth. From a theoretical perspective, much is made of the importance of spillovers (Grossman and Helpman, 1991; Barro and Sala-i-Martin,1995). De Mello (1999) hypothesises that FDI as a positive impact on growth through enhancing technological progress and the accumulation of physical and human capital. It can generate positive effects on productivity, competitiveness and job creation in host countries. A number of empirical studies support the hypothesis of the existence of a positive causal relationship between FDI and economic performance (Walsh and Yiu, 2010; Carcovick and Levine, 2005; Borensztein et al. 1995). 
There is also a burgeoning literature examining the relationship between financial development and growth, going back as far as Schumpeter (1911), who hypothesises that financial development enhances growth by reallocating resources to growth-inducing sectors and by promoting entrepreneurship in these sectors; more recent work on this hypothesis has been undertaken by Fung (2009). McKinnon and Shaw (1973) stress that financial liberalisation is a necessary but not sufficient condition to encourage investment in new technologies and technological progress. Later studies use an endogenous growth theory approach to study the impact of financial sector development on growth, stressing the important role of financial intermediaries in collecting and analysing information about firms and markets (Greenwood and Jovanovic, 1990), and the role of financial development in increasing the return on innovation by improving the evaluation of investment projects via information acquisition; by mobilising household savings for innovative endeavours; and through the ability to share and diversify risks and enhance the innovation of intermediate goods (King and Levine 1993). As noted by Levine (1997), better savings mobilisation not only increases capital accumulation, but it also improves resource allocation and boosts technological innovation. Other researchers hypothesise that economic growth causes financial development (Lucas, 1988; Stern, 1989). The empirical findings on the causal relationship between financial sector development and growth have been mixed (Baliamoune-Lutz, 2013; Ewetah and Okodua, 2013; Akinlo and Egbetunde, 2010; Dabos and Gantman, 2010).

Until relatively recently, there had been little in the way of studies looking at the co-dependency between FDI and financial development, but there has been an increasing recognition that the impact of FDI on growth can depend on the extent of financial sector development. These studies are based on the idea that as FDI inflows increase, the cost of innovation falls, and that financial sector development may increase the speed of innovation and technical spillovers from FDI. It is also hypothesised by Alfaro (2006) that this relationship may arise via backward linkages, insofar as financial sector development is able to facilitate linkages between foreign and domestic firms by easing credit constraint and lowering lending and deposit rates. Hermes and Lensink (2003) and Bailliu (2000) find that FDI only has a positive impact on growth if the financial sector is well developed. Alfaro et al. (2004) obtain a similar result using stock market indicators. Not all studies come to this conclusion: Durham (2004) and Carcovick and Levine (2005) have found that no significant evidence of this relationship, giving rise to the idea that the relationship may depend on the level of development of the financial sector of the country concerned. This possibility is reinforced by the findings of Chee and Nair (2010) who undertake a panel data study looking at 44 countries in Asia and Oceania, and find that the effect is strongest for the least developed countries of the region.

There is an interest to understand the causal relationship between these three elements; a better understanding of the dynamics of the relationship can have important policy implications. Using a similar approach to that proposed for this study, Choong et al. (2004) tested the co-dependency hypothesis for three developed countries and six East Asian countries in order to investigate the role of the domestic financial system in transferring the technological diffusion embodied in FDI inflows. They find that FDI and economic growth are not cointegrated by themselves directly but rather through their dynamic interaction with the development of the domestic financial sector, meaning that FDI will result in positive technology diffusion (and therefore growth) in the long run only if the evolution of the financial sector has reached a certain level. Adeniyi and Omisakin (2012) undertake a similar study looking five West African economies and find that for most of these countries financial sophistication matters for the benefits of FDI to register on economic growth.

This study will seek to enhance the literature in the third of these areas, namely investigating the relationship between financial sector development, FDI and economic growth, using data from East Africa. This region is an interesting case study because it includes a number of economically similar and interdependent countries, which have been successful in attracting FDI, which have significant differences in terms of financial sector development.

\section{METHODOLOGY AND DATA}

Causality testing is traditionally used to examine the short term relationship between variables, and usually either Granger or Sims tests are used (see Granger, 1969; Sims, 1972), which involves formulating null hypotheses as zero restrictions on the lagged coefficients of a subset of the variables. The problem with such tests is that they are grounded in asymptotic 
theory and consequently valid only for stationary variables. This means that for non-stationary variables (such as most macroeconomic variables) a vector autoregression must be estimated in differences in order for inferences based on asymptotic theory to be valid. However, unit root tests for stationarity tend to have low power, and typical time-series using macroeconomic data (which tends to be annual) means that sample sizes are relatively small. Consequently, this could result in incorrect inferences. In order to avoid these issues involved in the use of standard Granger causality tests, this paper uses a more appropriate methodology in the form of Toda and Yamamoto's (1995) test, which fits a standard vector autoregression in the levels of the variables, thereby minimising the risks associated with wrongly identifying the orders of intergration of the series (Giles, 1997, Kelly and Mavrotas, 2001). Given that Toda and Yamamoto's methodology intentionally overfits VARs and so may be inefficient when the number of variables and lag length are inappropriate, a sense check is undertaken by also performing standard Granger causality tests. In looking at the long-term relationship between the variables, Johansen and Juselius multivariate cointegration tests will be used (Johansen and Juselius, 1990), with stationarity testing undertaken using Augmented Dickey Fuller tests (ADF; Dickey and Fuller, 1981).

The Johansen and Juselius procedure involves creating a vector autoregression as follows:

$$
y_{t}=\mu+\sum_{i=1}^{p} A_{i} y_{t-i}+\varepsilon_{t}
$$

Where $y_{t}$ is a $(\mathrm{n} \times 1)$ vector of potentially endogenous stationary and non-stationary variables, $A$ is an $(n \times n)$ matrix of parameters, $\mu$ is a $(n \times 1)$ vector of constants and $p$ is the lag length. The system is in reduced form with each variable in y regressed only on lagged variables of both itself and the other variables in the system. This can be rearranged into an error correction mechanism (ECM) to give the following:

$$
\Delta y_{t}=\sum_{i=1}^{p-1} \Gamma_{i} \Delta y_{t-i}-\Pi y_{t-i}+\mu_{t}
$$

Where $\Gamma_{i}=-\left(I_{k}-A_{1}-\cdots-A_{i}\right), i=1, \ldots, p-1$

And $\Pi=I_{k}-A_{1}-\cdots A_{p}$

$\Pi$ is the long run matrix which can be written $\alpha \beta$, where $\alpha$ and $\beta$ are $(n \times r)$ matrices. $\beta$ 's cointegrating vectors are the ECMs, and $\alpha$ comprises the parameters which give the speed of adjustment of the system to long run equilibrium parameter levels. The rank $(r)$ of the matrix determines how many combinations of the dependent variables are stationary. We are interested in the case in which the matrix is of reduced rank, in other words there are $r$ stationary linear combinations of the dependent variables, as this suggests the variables are cointegrated. Cointegrating rank is determined using either the maximum eigenvalue test or the trace test.

The maximum eigenvalue test is undertaken as follows. Let $\lambda_{i}$ denote the estimated eigenvalues, where $i=1,2 \ldots \mathrm{n}$. Then the maximum eigenvalue test is calculated as:

$$
\lambda_{\max }=-T \log (1-\hat{\lambda} i)
$$

The null hypothesis is that there are $r=n$ cointegrating vectors, the alternative is that $r \leq n+1$.

The Trace test is similar to the maximum eigenvalue test:

$$
\text { Trace }=-T \sum_{i=r+1}^{n} \log (1-\hat{\lambda} i)
$$

In this case, the null hypothesis is again that there are $r=n$ cointegrating vectors, the alternative is that $r \leq n$.

Turning to data, obtaining data on GDP and FDI is straightforward, it is taken from the IMF's International Financial Statistics (IFS) database. The variables are both nominal and in local currency; in all cases the data are deflated. Finding a measure of financial sector development is more complex as there are a number of potential choices (see IMF, 2005). Often, researchers use measures of the size of the financial system relative to GDP (a typical one being broad money, or M2, to GDP). A quantification of the number and types of financial intermediaries is a useful measure of diversity and sophistication of the financial sector. There is also a wide range of potential measures based on competition, concentration and efficiency of intermediaries, such as the total cost of financial intermediation as a share of total assets. The issue with these measures is data availability, and this is a particular issue for developing economies. In the end, based on data availability considerations, a measure of claims by financial institutions on the private sector was used (CPS). This is available for all the countries included in the study in IFS, albeit only until 2008, and 
is a reasonable (and frequently used) proxy for financial sector development. The interaction term is constructed using the centred FDI and CPS variables. The series begin in 1985 for Burundi, 1992 for Ethiopia, 1980 for Kenya, 1981 for Rwanda, 1988 for Tanzania, and 1992 for Uganda. The relatively short length of the time series is not ideal, and robustness would be improved by using quarterly data in order to have more observations, however such data is not readily available for the variables being examined, and where available, its reliability cannot be assured. Likewise, the fact that the model does not extend beyond 2008 means that it does not capture the significant financial development that has occurred since this date in several of the countries. Although this may be seen as a limitation, in fact the model seeks to empirically test the theoretical relationship postulated in the literature, as such it is not critical that the most recent observations are not included.

A preview of the data does not reveal anything particularly unexpected. In most cases, GDP in real terms shows a steady increase over time, suggesting the series is non-stationary. The notable exceptions are Rwanda and Burundi, which both show a sharp fall in real GDP after the start of conflicts in 1993/4, recovery was particularly slow in Burundi, which experienced a prolonged civil war. In all cases, credit to the private sector (in real terms) has shown a steady increase, suggesting that the series is also non-stationary. Real FDI has been less predictable, with countries experiencing large fluctuations from one year to the next, reflecting on one side the sensitivity of investors to the macroeconomic and political environment (for example and on the other, the low granularity of such investment, such that a large investment one year can have a big impact on the overall figures. However, when smoothed using a moving average, the trend is generally positive apart from for Rwanda, which saw a large drop in FDI following the genocide, which has picked up again but remains significantly below the pre1994 period, and Ethiopia, which saw a fall in FDI in the 2004-2008 period.

\section{EMPIRICAL FINDINGS AND INTERPRETATION}

First we test for short run causality between GDP growth and FDI, and GDP growth and claims on the private sector. As discussed above, we use Toda and Yamamoto's methodology. The first stage of this process is to specify the model, which involves determining the optimal lag lengths of the levels of own and other variables in the model. This is done by minimising the Akaike's Information Criterion - this criterion improves on standard measures of goodness of fit such as RSS or R2 as it takes into account improvements in goodness of fit that arise simply due to increasing the number of explanatory variables in the model. Having calculated the appropriate lag lengths for the model, we can then specify the VAR. Its robustness is tested using misspecification tests. Having determined a lag length $k$, we then estimate a $(k+d)$ th order VAR where $d$ is the maximal order of integration that we suspect might occur in the process (The augmented Dickey-Fuller (ADF) test (Dickey and Fuller, 1981) is used to test for unit roots). The coefficient matrices of the last $d$ lagged vectors in the model are ignored (since these are regarded as zeros) and we can test linear or nonlinear restrictions on the first $k$ coefficient matrices using standard asymptotic theory.

The results of the lag length tests are included in annex. The econometric and statistical adequacy of the VAR model are verified to ensure that the model assumptions are supported by the data. System linearity is tested using the Ramsey RESET (R2) test1. Lagrange Multiplier tests (LM1-LM3) are used to test for departures from the independence assumption of the error term. Normality is tested using standard Jarque-Bera (JB) tests. The results of these tests are reported in Table 1.

The JB, LM and R2 tests indicate that the various models are appropriately specified. As discussed, performing the Toda and Yamamoto test involves adding extra lag of each of the variables to the equations based on the maximum expected order of integration (in this case two) and using a standard Wald test for coefficient restrictions to test whether the coefficients of the lagged 'other' variables (excluding the additional one) are jointly zero in the equation. Interestingly, in almost all cases there is no evidence of causality, indicating that there is no short-term relationship between FDI GDP growth. The only exception is in Tanzania, where there is evidence of a short term causal relationship from GDP growth to FDI. This result gives little support to the notion of a short term relationship from FDI to GDP growth. Standard Granger causality tests confirm these results.

Thus we turn to the question of a long term relationship between FDI and GDP growth. Stationarity

${ }^{1}$ Ramsey (1969). This test the functional form using the square of the fitted values; the null hypothesis is that the coefficients of higher order terms added to the regression are zero. 
Table 1: Misspecification Diagnostics

\begin{tabular}{|c|c|c|c|c|c|c|}
\hline Equation & Wald & JB & LM1 & LM2 & LM3 & $\mathrm{R} 2$ \\
\hline \multicolumn{7}{|l|}{ Burundi } \\
\hline FDI(GDP) & NA & NA & NA & NA & NA & NA \\
\hline \multicolumn{7}{|l|}{ Ethiopia } \\
\hline GDP(FDI) & 2.403 & 1.567 & 0.118 & 2.196 & 2.088 & 1.876 \\
\hline \multirow[t]{2}{*}{ FDI(GDP) } & 0.588 & 3.808 & 1.568 & 0.701 & 0.714 & 3.349 \\
\hline & 0.645 & 0.149 & 0.246 & 0.528 & 0.578 & 0.105 \\
\hline \multicolumn{7}{|l|}{ Kenya } \\
\hline GDP(FDI) & NA & NA & NA & NA & NA & NA \\
\hline FDI(GDP) & NA & NA & NA & NA & NA & NA \\
\hline \multirow[t]{2}{*}{ FDI(GDP) } & 11.567 & 1.269 & 0.439 & 1.684 & 6.76 & 1.469 \\
\hline & $0.005^{\star *}$ & 0.53 & 0.512 & 0.23 & 0.09 & 0.249 \\
\hline \multicolumn{7}{|l|}{ Uganda } \\
\hline GDP(FDI) & NA & NA & NA & NA & NA & NA \\
\hline \multirow[t]{2}{*}{ FDI(GDP) } & 2.224 & 1.165 & 0.06 & 1.7 & 6.602 & 0.281 \\
\hline & 0.224 & 0.559 & 0.814 & 0.273 & 0.05 & 0.615 \\
\hline
\end{tabular}

Figures in italics are $p$ values. ${ }^{*}$ indicates hypothesis rejected at the $1 \%$ level; Kenya and Burundi are noted as NA because the optimal lag lengths of 'other' variables in these cases was zero, intuitively suggesting no relationship exists.

\section{Table 2: Bivariate Cointegration Results}

\begin{tabular}{|c|c|c|c|c|c|}
\hline \multirow{2}{*}{ Country (data period) } & \multirow{2}{*}{$\begin{array}{l}\text { Null Hypothesis: } H^{\circ} \text { : } \\
\text { rank=p }\end{array}$} & \multicolumn{2}{|c|}{ Maximum Eigenvalue Test } & \multicolumn{2}{|c|}{ Trace Test } \\
\hline & & Test Statistic & Critical Value (95\%) & Test Statistic & Critical Value (95\%) \\
\hline \multirow[t]{2}{*}{ Burundi (1985-2008) } & $p=0$ & 10.129 & 14.265 & 11.752 & 15.495 \\
\hline & $\mathrm{p} \leq 1$ & 1.623 & 3.841 & 1.623 & 3.841 \\
\hline \multirow[t]{2}{*}{ Ethiopia (1992-2008) } & $p=0$ & 3.659 & 14.265 & 3.766 & 15.495 \\
\hline & $p \leq 1$ & 0.106 & 3.841 & 0.106 & 3.841 \\
\hline \multirow[t]{2}{*}{ Kenya (1980-2008) } & $p=0$ & $22.826^{*}$ & 14.265 & $27.944^{*}$ & 15.495 \\
\hline & $p \leq 1$ & $5.117^{*}$ & 3.841 & $5.117^{*}$ & 3.841 \\
\hline \multirow[t]{2}{*}{ Rwanda (1981-2005) } & $\mathrm{p}=0$ & 8.793 & 14.265 & 10.584 & 15.495 \\
\hline & $p \leq 1$ & 1.791 & 3.841 & 1.791 & 3.841 \\
\hline \multirow[t]{2}{*}{ Tanzania (1988-2008) } & $p=0$ & $29.648^{*}$ & 14.265 & $31.226^{*}$ & 15.495 \\
\hline & $\mathrm{p} \leq 1$ & 1.578 & 3.841 & 1.578 & 3.841 \\
\hline \multirow[t]{2}{*}{ Uganda (1993-2008) } & $p=0$ & 10.634 & 14.265 & 10.658 & 15.495 \\
\hline & $p \leq 1$ & 0.025 & 3.841 & 0.025 & 3.841 \\
\hline
\end{tabular}

${ }^{*}$ indicates hypothesis rejected at $5 \%$ level.

tests were undertaken using Augmented Dickey Fuller tests (Dickey and Fuller, 1981), and all variables were discovered to be non-stationary in levels, but stationary in their first differences ${ }^{2}$. Table 2 shows the bivariate

\footnotetext{
${ }^{2}$ Results available from the author on request.
}

findings, namely the results of the Johansen and Juselius tests for cointegration between GDP and FDI. The findings indicate evidence of two cointegrating vectors in Kenya, and one cointegrating vector in Tanzania, but no cointegration in the other countries.

Now we move on to test the main hypothesis of the paper, which is that there is a co-dependency between 
Table 3: Multivariate Cointegration Results

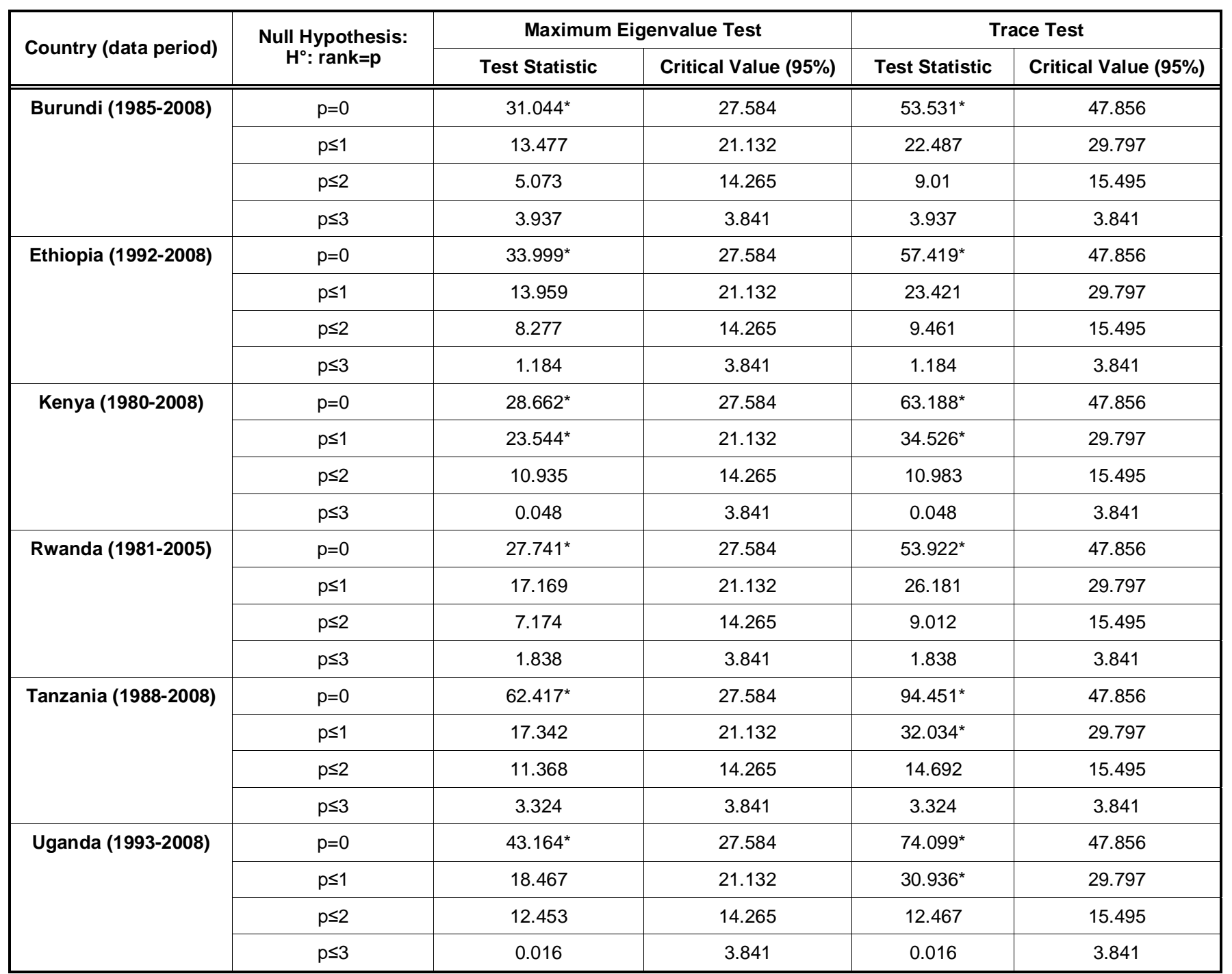

*indicates hypothesis rejected at $5 \%$ level.

financial development and FDI, namely that the impact of FDI on growth depends on financial sector development. In order to test this we create a multivariate VAR, adding the indicator of financial development, claims on the private sector (CPS) and the interactive term between FDI and financial sector development into the VAR. The results are given in Table 3.

The findings here are very interesting as there is clear evidence of the presence of cointegrating relationships when FDI and CPS are included together in the VAR - there is now evidence of a cointegration vector in Burundi, Ethiopia, Rwanda and Uganda, the countries for which no relationship was found in the bivariate case. This result is interesting and reinforces the findings of Choong et al. (2004) for East Asia.
We need to further investigate the nature of these cointegrating relationships before we can conclude that financial sector development plays an instrumental role in the relationship between FDI and GDP growth. Table 4 looks at the cointegrating vectors, normalised on GDP.

The positive coefficient on the CPSFDI indicator in the above table indicates that in three countries, namely Kenya, Rwanda and Uganda, financial sector development, as measured by claims on the private sector has had a positive impact in ensuring that FDI flows generate growth. In line with the findings of Choong et al. (2004), in most cases in which the coefficient on CPSFDI is positive, the coefficient on FDI is negative and vice versa (Uganda being the exception). Choong et al. conclude that these results suggest that FDI will have a positive impact on 
Table 4: Estimated Cointegrating Vectors

\begin{tabular}{|c|c|c|c|c|}
\hline Countries (data period) & GDP & FDI & CPS & CPSFDI \\
\hline \hline Burundi (1985-2008) & 1 & 1.815 & 2.877 & -0.606 \\
\hline Ethiopia (1992-2008) & 1 & 0.001 & -4.550 & -0.367 \\
\hline Kenya (1980-2008) & 1 & -0.567 & -2.497 & 0.583 \\
\hline Rwanda (1981-2005) & 1 & -0.560 & -0.870 & 0.239 \\
\hline Tanzania (1988-2008) & 1 & 0.641 & -6.107 & -0.277 \\
\hline Uganda (1993-2008) & 1 & 0.017 & -5.670 & 0.579 \\
\hline
\end{tabular}

economic performance only for those countries with well-developed and functioning financial systems; in the absence of such, the effect of FDI on growth is negative. Choong et al. note that the finding of an inverse relationship between the variables is in line with the literature, and could arise for two reasons, provided by Al-Yousif (2002), namely due to a business-cycle effect, or due to the inefficiency of the domestic financial sector in allocating resources and operating in a weak regulatory environment. This inefficiency among financial intermediaries actually slows growth down.

\section{CONCLUSION}

This study looks at the under-researched relationship between FDI, GDP growth and financial sector development, notably investigating the extent to which the last of these helps establish a long run relationship between FDI and GDP growth. We use a methodology which is robust to the weaknesses of traditional Granger-causality testing in order to test whether a short term causal relationship exists between these variables in a number of East African countries, but no significant evidence is found of such a relationship. Using Johansen cointegration tests, we only find evidence of a long run relationship from GDP growth to FDI in the case of Tanzania, no other long run relationships are discovered in the other countries. However, once variables are included to account for financial sector development, long run relationships become apparent. In three countries (Kenya, Uganda, and Rwanda) it is clear that financial sector development has a positive impact in ensuring that FDI flows generate growth. These countries are generally accepted as being the countries with the most developed financial sectors in the region, which gives clear policy recommendations, notably that efforts should be focused on developing the financial sector in order to reap the full benefits of FDI inflows.

\section{ACKNOWLEDGEMENT}

The author is grateful to two anonymous referees for constructive comments and suggestions that substantially improved the paper. Any remaining errors are the responsibility of the author. The findings in this paper do not necessarily reflect the views of the European Investment Bank.

ANNEX: Lag Structure: Akaike Information Criteria Statistic

\begin{tabular}{|c|c|c|c|c|}
\hline & \multicolumn{4}{|c|}{ Lags } \\
\hline & 0 & 1 & 2 & 3 \\
\hline \multicolumn{5}{|l|}{ Burundi } \\
\hline \multicolumn{5}{|c|}{ Dependent Variable } \\
\hline GDP & 55.999 & 54.619 & 54.613 & 54.718 \\
\hline FDI & 55.957 & 56.015 & 56.157 & 56.276 \\
\hline \multicolumn{5}{|c|}{ Other variable lags } \\
\hline GDP(FDI) & 54.613 & 54.682 & 54.712 & 54.813 \\
\hline FDI(GDP) & 55.937 & 55.981 & 56.123 & 56.241 \\
\hline \multicolumn{5}{|l|}{ Ethiopia } \\
\hline \multicolumn{5}{|c|}{ Dependent Variable } \\
\hline GDP & 52.828 & 49.722 & 49.78 & 49.866 \\
\hline FDI & 56.304 & 56.018 & 56.197 & 56.059 \\
\hline \multicolumn{5}{|c|}{ Other variable lags } \\
\hline GDP(FDI) & 49.722 & 49.833 & 49.593 & 49.672 \\
\hline FDI(GDP) & 56.018 & 55.775 & 55.808 & 55.213 \\
\hline \multicolumn{5}{|l|}{ Kenya } \\
\hline \multicolumn{5}{|c|}{ Dependent Variable } \\
\hline GDP & 56.217 & 54.775 & 54.588 & 54.698 \\
\hline FDI & 58.696 & 58.756 & 58.791 & 58.242 \\
\hline \multicolumn{5}{|c|}{ Other variable lags } \\
\hline GDP(FDI) & 54.588 & 54.659 & 54.708 & 54.775 \\
\hline FDI(GDP) & 58.242 & 58.313 & 58.343 & 58.419 \\
\hline
\end{tabular}




\begin{tabular}{|c|c|c|c|c|}
\hline \multicolumn{5}{|l|}{ Rwanda } \\
\hline \multicolumn{5}{|c|}{ Dependent Variable } \\
\hline GDP & 55.85 & 54.963 & 55.056 & 55.172 \\
\hline FDI & 57.041 & 56.032 & 56.037 & 56.099 \\
\hline \multicolumn{5}{|c|}{ Other variable lags } \\
\hline GDP(FDI) & 54.963 & 55.043 & 55.163 & 55.295 \\
\hline FDI(GDP) & 56.032 & 56.088 & 56.21 & 56.305 \\
\hline \multicolumn{5}{|l|}{ Tanzania } \\
\hline \multicolumn{5}{|c|}{ Dependent Variable } \\
\hline GDP & 61.911 & 56.906 & 56.907 & 56.988 \\
\hline FDI & 65.635 & 64.913 & 64.835 & 64.126 \\
\hline \multicolumn{5}{|c|}{ Other variable lags } \\
\hline GDP(FDI) & 56.906 & 56.942 & 56.788 & 56.957 \\
\hline FDI(GDP) & 64.126 & 64.016 & 63.293 & 63.249 \\
\hline \multicolumn{5}{|l|}{ Uganda } \\
\hline \multicolumn{5}{|c|}{ Dependent Variable } \\
\hline GDP & 61.571 & 57.109 & 57.071 & 56.772 \\
\hline FDI & 66.034 & 64.171 & 63.29 & 62.23 \\
\hline \multicolumn{5}{|c|}{ Other variable lags } \\
\hline GDP(FDI) & 56.772 & 56.909 & 56.892 & 56.992 \\
\hline FDI(GDP) & 62.23 & 61.819 & 61.445 & 61.595 \\
\hline
\end{tabular}

Figures in italics indicate the optimal lag length based on minimising the AIC Information Criteria.

\section{REFERENCES}

Adeniyi, Oluwatosin and Olesegun Omisakin. 2012. "Foreign Direct Investment, Economic Growth and Financial Sector Development in Small Open Developing Economies." Economic Analysis and Policy 42(1): 105-127. http://dx.doi.org/10.1016/S0313-5926(12)50008-1

Akinlo, Anthony and Tajudeen Egbetunde. 2010. "Financial Development and Economic Growth: the Experience of 10 Sub-Saharan African Countries Revisited." The Review of Finance and Banking 2(1): 17-28

Alfaro, Laura, Areendam Chanda, Sebnem Kalemli-Ozcan, and Selin Sayek. 2006. "How does FDI promote Economic Growth? Exploring the Effects of Financial Markets on Linkages." NBER Working Paper 12522.

Alfaro, Laura, Areendam Chanda, Sebnem Kalemli-Ozcan, and Selin Sayek. 2004. "FDI and Economic Growth: The Role of Local Financial Markets." Journal of International Economics 64: 89-112.

http://dx.doi.org/10.1016/S0022-1996(03)00081-3

Al-Yousif, Yousif Khalifa. 2002. "Financial Development and Economic Growth: Another Look at the Evidence from Developing Countries." Review of Financial Economics 11: 131-50. http://dx.doi.org/10.1016/S1058-3300(02)00039-3

Bailliu, Jeannine. 2000. "Private Capital Flows, Financial Development and Economic Growth in Developing Countries." Bank of Canada Working Paper 2000(15).

Baliamoune-Lutz, Mina. 2013. "Financial Development and Income in African Countries. Contemporary Economic Policy 31(1): 163-175.

http://dx.doi.org/10.1111/j.1465-7287.2011.00281.x
Barro, Robert and Xavier Sala-i-Martin. 1995. Economic Growth. New York: McGraw Hill.

Borensztein, Eduardo, José de Gregorio and Jong-Wha Lee. 1995. "How Does Foreign Direct Investment Affect Economic Growth?" NBER Working Paper 5057.

Calderon, Cesar and Lin Liu. 2003. "The direction of Causality between Financial Development and Economic Growth." Journal of Development Economics 72: 321-334. http://dx.doi.org/10.1016/S0304-3878(03)00079-8

Carcovick, Maria and Ross Levine. 2005. "Does FDI Accelerate Economic Growth?" pp. 195-220 In Moran, Theodore, Edward Graham and Magnus Blomstrom. Does Foreign Direct Investment Promote Growth? Washington DC: Institute for International Economics.

Chee, Yen Li and Mahendhiran Nair. 2010. "The Impact of FDI and Financial Sector Development on Economic Growth: Empirical Evidence from Asia and Oceania." International Journal of Economics and Finance 2(2): 107-119. http://dx.doi.org/10.5539/ijef.v2n2p107

Choong, Chee-Keong, Zulkornain Yusop and Siew-Choo Soo. 2004 "Foreign Direct Investment, Economic Growth and Financial Sector Development: a Comparative Analysis." ASEAN Economic Bulletin 21: 278-289. http://dx.doi.org/10.1355/AE21-3B

De Mello, Luiz.1999. "Foreign Direct Investment-Led Growth: Evidence from Time Series and Panel Data." Oxford Economic Papers 51: 133-151. http://dx.doi.org/10.1093/oep/51.1.133

Durham, J. Benson. 2004. "Absorptive Capacity and the Effects of Foreign Direct Investment and Equity Foreign Portfolio Investment on Economic Growth." European Economic Review 48: 285-306. http://dx.doi.org/10.1016/S0014-2921(02)00264-7

Ewetan, Olabanji and Henry Okodua. 2013. "Is there a Link between Financial Sector Development and Economic Growth in Nigeria?" International Journal of Financial Economics 1(4): 108-118.

Fung, Michael. 2009. "Financial Development and Economic Growth: Convergence or Divergence?" Journal of International Money and Finance 28: 56-78. http://dx.doi.org/10.1016/j.jimonfin.2008.08.001

Greenwood, Jeremy and Boyan Jovanovic. 1990. "Financial Development, Growth and the Distribution of Income." Journal of Political Economy 98: 1076-1087. http://dx.doi.org/10.1086/261720

Grossman, Gene and Ethan Helpman.1991. Innovation and Growth in the Global Economy. Cambridge MA: MIT Press.

Hermes, Niels and Robert Lensink. 2003. "Foreign Direct Investment, Financial Development and Economic Growth." The Journal of Development Studies 40: 142-163. http://dx.doi.org/10.1080/00220380412331293707

IMF. 2005. Financial Sector Assessment: a Handbook. International Monetary Fund. http://www.imf.org/external/pubs/ft/fsa/eng/ pdf/cover.pdf

Johansen, Soren and Katarina Juselius. 1990. "Maximum Likelihood Estimation and Inference on Cointegration with Applications to the Demand for Money." Oxford Bulletin of Economics and Statistics 52: 169-211. http://dx.doi.org/10.1111/j.1468-0084.1990.mp52002003.x

Kelly, Roger and George Mavrotas. 2001. "Old Wine in New Bottles: Testing Causality between Saving and Growth." The Manchester School 69: 97-105. http://dx.doi.org/10.1111/1467-9957.69.s1.6

King, Robert and Ross Levine.1993. "Finance and Growth: Schumpeter Might be Right." The Quarterly Journal of Economics 108: 717-737. http://dx.doi.org/10.2307/2118406 
Levine, Ross. 1997. "Financial Development and Economic Growth: Views and Agenda." Journal of Economic Literature 35: 688726.

Lucas, Robert. 1988. "On the Mechanics of Economic Development." Journal of Monetary Economics 22: 3-42. http://dx.doi.org/10.1016/0304-3932(88)90168-7

McKinnon, Ronald and Edward Shaw. 1973. Money and Capital in Economic Development. Washington DC: Brookings Institution.

Schumpeter, Joseph. 1911. The Theory of Economic Development: and Inquiry into Profits, Capital, Credit, Interest and the Business Cycle. Cambridge MA: Harvard University Press.
Stern, Nicholas. 1989. "Financial Development and Economic Growth: Views and Agenda." Journal of Economic Literature XXXV: 688-726.

Toda, Hiro and Taku Yamamoto. 1995. "Statistical Inference in Vector Autoregressions with Possibly Integrated Processes." Journal of Econometrics 66: 225-250. http://dx.doi.org/10.1016/0304-4076(94)01616-8

Walsh, James and Jiangyan Yiu. 2010. "Determinants of Foreign Direct Investment: a Sectoral and Institutional Approach." IMF Working Paper 187.

Received on 15-04-2016

DOI: http://dx.doi.org/10.6000/1929-7092.2016.05.12

(C) 2016 Roger Kelly; Licensee Lifescience Global.

This is an open access article licensed under the terms of the Creative Commons Attribution Non-Commercial License (http://creativecommons.org/licenses/by-nc/3.0/) which permits unrestricted, non-commercial use, distribution and reproduction in any medium, provided the work is properly cited. 